\title{
Assessment of Different Priming Methods on Germination and Quality Parameters of Coriander (Coriandrum sativum L.)
}

\author{
A. Neha Reddy*, A. K. Chaurasia and Ehunme Sutnga
}

Department of genetics and plant breeding, Seed Testing Laboratory, Sam Higginbottom

University of Agriculture, Technology\& Sciences, Prayagraj, India

*Corresponding author

\section{A B S T R A C T}

\section{Keywords}

Coriander, Hydro priming, Osmo priming, Halo priming, Hormonal priming, Organic priming, $\mathrm{GA}_{3}$, $\mathrm{PEG}$ $6000, \mathrm{KH}_{2} \mathrm{PO}_{4}$, $\mathrm{KNO}_{3} \mathrm{NaCl}$, Tulasi leaf extract and Moringa leaf extract

Article Info

Accepted:

22 October 2020

Available Online:

10 November 2020
Coriander is an important spice crop and occupies a prime position in flavouring substances and is available throughout the year providing a fragrant flavour. Seed Spices are annual herbs, whose dried seed or fruits are used as spices. They are nature's gift to mankind and add flavour to our food in addition to having preservative and medicinal value. So being considerate with the importance of Coriander, the present study emphasizes "Assessment of different priming methods on germination and quality parameters of coriander (Coriandrum sativum L.)" was undertaken with the objectives to assess the performance of different priming methods on improvement of germination and quality parameters in coriander and to identify the better responding priming method for coriander. The study was conducted in Department of Genetics and Plant Breeding, Seed Testing Laboratory, Sam Higginbottom University of Agriculture, Technology and Sciences, Prayagraj, Uttar Pradesh, during 2019-2020. The experiment conducted was treated with different methods of priming for 12 hours and were shade dried in completely randomized design (CRD) with four replications, and analysed for germination and quality parameters. The experiment showed the organic treatment i.e Moringa Leaf Extract (MLE) attained the highest value in germination and quality parameters. Hence, the results concluded that the organic priming treatment Moringa Leaf Extract (MLE 5\%) was found to be better and can be effectively used as low cost, environmentally friendly, easily adaptable priming method by farmers.

\section{Introduction}

Coriander (Coriandrum sativum L.) is an annual plant, possessing $2 \mathrm{n}=22$ chromosomes with cross pollination as mode of reproduction which is native to the Southern Europe and North Africa to South Western Asia (Mouterde 1986) and is extensively grown in Bangladesh, India, Russia, Central
European Morocco. It belongs to the Umbelliferae (Apiaceae) family and genus Coriandrum embrace cultivated plant (Coriandrum sativum) and wild species (Coriandrum tordylium). Coriander is a tropical crop; it requires a cool and comparatively dry frost, free climate particularly at the time of flowering and seed formation stages, for good quality and high 
yields. The optimum temperature of germination and early growth of coriander is $20-25^{\circ} \mathrm{C}$. The germination is epigeal and the plant has a tap root.

Coriander is referred to as "kusthumbari" or "dhanayaka" in the Sanskrit literature (Prakash, 1990). Out of the total 75 spices grown in India, 20 are classified as seed spices with 44 per cent share in area and 21 per cent share in production of total spice in India. It is mainly cultivated for the seeds, whereas the leaves are used as a garnish purpose (Kiralan et al., 2009). The typical staggered flowering behaviour of coriander resulted invariable fruit formation and leading to slow and uneven germination in coriander seeds (Rubatzky et al., 1999).

It is mainly cultivated as a rabi crop in India as Coriander requires cool climate during growth and warm dry climate during seed maturity. It can be cultivated in all types of soils but comes up well on well drained loamy soils. Though it is cultivated across the country but production is concentrated in Madhya Pradesh, Rajasthan, Gujarat, Assam, West Bengal, Orissa, Uttar Pradesh and Andhra Pradesh. India is the largest producer and consumer of coriander seed. Spices Board data showed coriander area and production in the country reached 544240 hectares, 721390 tons in 2017-18 and 469900 hectares, 600410 tons in 2018-19 respectively.

The major leading state wise in area (hectare) and production (tons) are Madhya Pradesh (279980,378230) Rajasthan (68784,89306) Gujarat (30136,45418) Assam (29749,30790) West Bengal (11803,15055) Orissa (19610,10863) Uttar Pradesh (6635,5259) Andhra Pradesh $(1569,360)$ in 2018-19 respectively. (www.indianspices.com)

Coriander seeds have a health-supporting reputation that is high on the list of the healing spices. In parts of Europe, coriander has traditionally been referred to as an "antidiabetic" plant. In some parts of India, it has traditionally been used for its antiinflammatory properties. In the United States, coriander has recently been studied for its cholesterol lowering effects. The seeds are used in medicine as a carminative, diuretic and also used in the preparation of many house hold medicines to cure bed cold, seasonal fever, nausea, and stomach disorders. Coriandrum sativum is effective as both a treatment and preventive agent for several chronic diseases. Being aromatic and medicinal plant can be used as antispasmodic, appetite stimulant, stomachic, diuretic, anti-inflammatory and anti-diarrheic agent (Zargari, 1991; Mir Heidar, 1992).

The primary quality determinant of the spice is the content and composition of its steamvolatile oil. The volatile oil content of the spice can vary considerably according to the type and source and usually ranges from 0.1 to $1.7 \%$ and, in some cases, up to $2.7 \%$. During storage, some of the volatile oil can be lost by evaporation, but the rate of loss and the extent of organoleptic deterioration are dependent on the physical form of the spice and on the conditions and duration of storage.

Seed germination is one of the most saltsensitive plant growth stages and is severely inhibited with increasing salinity (Bouda and Haddioui, 2011). For this reason, several approaches including hardening, seed priming, seed soaking and seed coating have been employed to improve germination under salt stress.

Priming is simply process done prior to conventional seed germination which allows the inhibiting mechanism to be broken and the metabolic speed increase to begin leading to increase germination percentage by germinating seeds at much higher speed. 
There are several different methods for seed priming including the osmo priming, halo priming, hydro-priming and organic priming and matric priming (Esivand et al., ). Special priming treatments such as osmopriming, hydropriming, matric priming and hormonal priming have been tested (Basra et al., 2003). Seed priming is the imbibition of seeds in water sufficient for pre germinative metabolic activity to occur while preventing radical emergence (Basra at al. 2003). The seeds are then dried and will generally exhibit more rapid rates of radical emergence upon subsequent imbibition (Khan et al., 1992) which lead to acceleration of seed germination and seedling establishment under both normal and stressful environments (Ashraf and Foolad, 2005). The technique is simple, cheap and does not require expensive chemicals or sophisticated equipment. It could be recommended to farmers to achieve higher germination and uniform emergence under field conditions. Both ionic (Cayuela et al., 1996) and non-ionic (Atherton and Farooque 1983) compounds have been used effectively as priming agents (Bradford 1986). This technique can cause more rapid appearance of roots and stems, production of plants with stronger stamina, higher tolerance to drought, earlier flowering, early harvesting, and to obtain crop in bad conditions (Kaur et $a l .$,$) .$

\section{Materials and Methods}

The research study was conducted in the Department of genetics and plant breeding, Seed Testing Laboratory, Sam Higginbottom University of Agriculture, Technology\& Sciences, Prayagraj during 2019- 2020 to know the best priming method for Coriander.

The seeds of coriander were treated with methods of priming viz. $\mathrm{T}_{0}$ control, $\mathrm{T}_{1-}$ distilled water (hydro priming), $\mathrm{T}_{2}-\mathrm{GA}_{3}(100$ ppm) (hormonal priming), $\mathrm{T}_{3}-\mathrm{GA}_{3}(250 \mathrm{ppm}$ ) (hormonal priming), $\mathrm{T}_{4} \& \mathrm{~T}_{5}-\mathrm{KNO}_{3}(1 \% \&$ $3 \%), \mathrm{T}_{6} \& \mathrm{~T}_{7}-\mathrm{NaCl} \quad(1 \% \quad \& \quad 3 \%), \mathrm{T}_{8} \quad \& \mathrm{~T}_{9}$ $\mathrm{KH}_{2} \mathrm{PO}_{4} \quad\left(1 \%\right.$ \& $3 \%$ ) (halo priming) $\mathrm{T}_{10-}$ Tulasi Leaf Extract (TLE 5\%), $\mathrm{T}_{11}$ - Moringa Leaf Extract (MLE 5\%) (organic priming) and $\mathrm{T}_{12}$-PEG 6000 (osmo priming), for 12 hours and were shade dried. Hundred seeds of each treatment were placed for germination in four Replications in Complete Randomized Design (CRD). The between paper method used for samples and place for germination in germination chamber al $25{ }^{\circ} \mathrm{C}$ temperature. Germination and quality parameters i.e. Germination Percentage (\%), Speed of germination, Root length $(\mathrm{cm})$, Shoot length (cm), Seedling length $(\mathrm{cm})$, Fresh weight of seedling (g), Dry weight of seedling (g), Seed vigour index I and Seed vigour index II was analysed.

\section{Preparation of solutions (halo priming, osmo priming and hormonal priming)}

For the preparation of solution of the growth hormone $\mathrm{GA}_{3}, 100 \mathrm{mg}$ and $250 \mathrm{mg}$ of chemical were taken in each of two beakers. These chemicals were added in $1000 \mathrm{ml}$. of distilled water with constant stirring in each beaker. The volume of solution will finally constitute to one litter and then it became $100 \mathrm{ppm}$ and 250ppm solution of each chemical. The flasks containing chemicals will be covered with muslin cloth to avoid any contamination.

The solution of $\mathrm{KH}_{2} \mathrm{PO}_{4}(1.0 \%$ \& $3 \%)$ was prepared by dissolving $1 \mathrm{gm}$ and $3 \mathrm{gm}$ of $\mathrm{KH}_{2} \mathrm{PO}_{4}$ in distilled water to make the volume up to $100 \mathrm{ml}$.

The solution of $\mathrm{KNO}_{3} \quad(1 \% \& 3 \%)$ was prepared by dissolving $1 \mathrm{gm}$ and $3 \mathrm{gm}$ of $\mathrm{KNO}_{3}$ in distilled water to make the volume up to $100 \mathrm{ml}$.The solution of $\mathrm{NaCl}(1 \% \& 3 \%)$ was prepared by dissolving $1 \mathrm{gm}$ and $3 \mathrm{gm}$ of $\mathrm{NaCl}$ in distilled water to make the volume up to $100 \mathrm{ml}$. 
Preparation of plant leaf extract (Organic priming)

Tulasi leaves and Moringa leaves were collected from the Horticulture research fields, SHUATS. The leaves were washed thoroughly in tap water and crushed into fine paste by using mortar and pestle, each $5 \mathrm{~g}$ of the sample was ground by a blender with $100 \mathrm{ml}$ of distilled water. The ground mixture is filtered through a fine cotton cloth which constitutes 5\% Tulasi Leaf Extract and 5\% Moringa Leaf Extract.

\section{Results and Discussion}

\section{Analysis of variance}

The analysis of variance for seed quality characters was presented in Table 1. The analysis of variance revealed the significant difference of priming methods for all characters studied like germination percentage, speed of germination, root length $(\mathrm{cm})$, shoot length $(\mathrm{cm})$, seedling length $(\mathrm{cm})$, seedling fresh weight $(\mathrm{g})$, seedling dry weight $(\mathrm{g})$, seed vigour index I and seed vigour index II.

\section{Mean performance}

Mean performance of various priming methods on different characters was showed in the Table 2.

\section{Germination \%}

Germination percentage was significantly influenced by different seed treatments. Mean performance of seed germination ranged from $97.25 \%$ to $76.25 \%$ with mean value of $89.5 \%$. Seed treated with Moringa Leaf Extract (5\%) $\left(\mathrm{T}_{11}\right)$ recorded significantly highest germination percentage $(97.25 \%)$ followed by distilled water i.e hydro priming $\left(\mathrm{T}_{1}\right)$ with $(96.75 \%)$. The minimum (76.25\%) was observed in control $\left(\mathrm{T}_{0}\right)$. similar finding results reported by H.A. Wajid et al., (2018), Afzal et al., (2012), Azra Yasmeenet al., (2013), Hala et al., (2017) and Wasif Nouman et al., (2012).

\section{Speed of germination}

Speed of Germination was significantly influenced by different seed treatments. Mean performance of speed of germination ranged from 41.485 to 28.465 with mean value of 36.00904. Seed treated with Moringa Leaf Extract $(5 \%) \quad\left(\mathrm{T}_{11}\right)$ recorded significantly highest speed of germination (41.485) followed by distilled water i.e. hydro priming $\left(\mathrm{T}_{1}\right)$ with (40.0825). The minimum (28.465) was observed in control $\left(\mathrm{T}_{0}\right)$. Alike evident of speed of germination was observed by Anisa Ruttanaruangboworn et al., (2017).

\section{Root length (cm)}

Root length $(\mathrm{cm})$ was significantly influenced by different seed treatments. Mean performance of root length ranged from $9.245 \mathrm{~cm}$ to $6.1325 \mathrm{~cm}$ with mean value of $7.885769 \mathrm{~cm}$. Seed treated with Moringa Leaf Extract $(5 \%) \quad\left(\mathrm{T}_{11}\right)$ recorded significantly highest root length $(9.245 \mathrm{~cm})$ followed by distilled water i.e. hydro priming $\left(\mathrm{T}_{1}\right)$ with $(8.7175 \mathrm{~cm})$. The minimum $(6.1325)$ was observed in control $\left(\mathrm{T}_{0}\right)$. Similar results of root length were discussed as Afzal et al., (2012), Azra Yasmeen et al., (2013) and Hala et al., (2017).

\section{Shoot length $(\mathrm{cm})$}

Shoot Length (cm) was significantly influenced by different seed treatments. Mean performance of shoot length ranged from $17.24 \mathrm{~cm}$ to $11.8375 \mathrm{~cm}$ with mean value of 15.32846. Seed treated with Moringa Leaf Extract $(5 \%) \quad\left(\mathrm{T}_{11}\right)$ recorded significantly highest length of shoot $(17.24 \mathrm{~cm})$ followed by 
distilled water i.e., hydro priming $\left(\mathrm{T}_{1}\right)$ with $(16.275 \mathrm{~cm})$. The minimum $(11.8375)$ was observed in control $\left(T_{0}\right)$. Similar results of shoot length were discussed by Afzal et al., (2012), Azra Yasmeen et al., (2013) and Hala et al., (2017) recommended that soaking pepper seeds in MLE solution at concentrate of $4 \%$ for 6hours enhanced the seedling characters.

\section{Seedling length $(\mathrm{cm})$}

Seedling Length $(\mathrm{cm})$ was significantly influenced by different seed treatments. Mean performance of seedling length ranged from $26.485 \mathrm{~cm}$ to $17.97 \mathrm{~cm}$ with mean value of 23.21423. Seed treated with Moringa Leaf Extract $(5 \%) \quad\left(\mathrm{T}_{11}\right)$ attained significantly highest length of seedling $(26.485 \mathrm{~cm})$ followed by distilled water i.e., hydro priming $\left(\mathrm{T}_{1}\right)$ with $(24.9952 \mathrm{~cm})$. The minimum (17.97) was observed in control $\left(T_{0}\right)$. Similar results of seedling length were discussed by Afzal $e t$ al., (2012), Azra Yasmeen et al., (2013) and Hala et al., (2017).

\section{Seedling fresh weight $(\mathrm{g})$}

Seedling Fresh Weight (g) was determined by different seed treatments. Mean performance of seedling fresh weight ranged from $1.907 \mathrm{~g}$ to $1.375 \mathrm{~g}$ with mean value of 1.554308 . Seed treated with Moringa Leaf Extract (5\%) $\left(\mathrm{T}_{11}\right)$ accomplished significantly highest Fresh weight of seedling $(1.907 \mathrm{~g})$ followed by distilled water i.e., hydro priming $\left(\mathrm{T}_{1}\right)$ with $(1.825 \mathrm{~g})$. The minimum (1.375) was observed in control $\left(\mathrm{T}_{0}\right)$. Similar results of seedling fresh weight were discussed by Afzal et al., (2012), Azra Yasmeen et al., (2013) and Hala et al., (2017).

Table.1 Analysis of variance for seed quality characters in coriander

\begin{tabular}{|c|l|c|c|}
\hline \multicolumn{4}{|c|}{ Mean Sum of Squares } \\
\hline S.No & \multicolumn{1}{|c|}{ Parameters } & Treatment & Error \\
\hline $\mathbf{1}$ & Seed Germination & 245.292 & 7.987 \\
\hline $\mathbf{2}$ & Speed of Germination & 69.047 & 7.296 \\
\hline $\mathbf{3}$ & Root Length & 2.897 & 0.567 \\
\hline $\mathbf{4}$ & Shoot Length & 7.409 & 0.875 \\
\hline $\mathbf{5}$ & Seedling Length & 15.907 & 1.783 \\
\hline $\mathbf{6}$ & Seedling Fresh Weight & 0.122 & 0.011 \\
\hline $\mathbf{7}$ & Seedling Dry Weight & 0.003 & 0.001 \\
\hline $\mathbf{8}$ & Seedling Vigour Index I & 387328.890 & 21446.025 \\
\hline $\mathbf{9}$ & Seedling Vigour Index II & 28.828 & 4.676 \\
\hline *Significant at 5\% level of significance. & & \\
\hline
\end{tabular}


Table.2 Mean performance of various priming methods on different characters

\begin{tabular}{|c|c|c|c|c|c|c|c|c|c|c|}
\hline S.No & Treatments & $\begin{array}{l}\text { Germination } \\
\text { Percentage }\end{array}$ & $\begin{array}{c}\text { Speed of } \\
\text { Germination }\end{array}$ & $\begin{array}{c}\text { Root } \\
\text { Length } \\
\text { (cm) }\end{array}$ & $\begin{array}{c}\text { Shoot } \\
\text { Length } \\
\text { (cm) }\end{array}$ & $\begin{array}{l}\text { Seedling } \\
\text { Length } \\
(\mathrm{cm})\end{array}$ & $\begin{array}{c}\text { Seedling } \\
\text { Fresh } \\
\text { Weight } \\
\text { (g) }\end{array}$ & $\begin{array}{c}\text { Seedling } \\
\text { Dry } \\
\text { Weight } \\
\text { (g) }\end{array}$ & $\begin{array}{l}\text { Seedling } \\
\text { vigour } \\
\text { Index I }\end{array}$ & $\begin{array}{c}\text { Seedling } \\
\text { Vigour } \\
\text { Index II }\end{array}$ \\
\hline 1 & $\mathbf{T}_{0}$ & 76.25 & 28.465 & 6.1325 & 11.8375 & 17.97 & 1.375 & 0.0175 & 1371.18 & 1.3025 \\
\hline 2 & $\mathbf{T}_{1}$ & 96.75 & 40.0825 & 8.7175 & 16.275 & 24.9925 & 1.825 & 0.085 & 2418.72 & 8.2125 \\
\hline 3 & $\mathbf{T}_{2}$ & 77 & 30.2425 & 7.7925 & 15.4175 & 23.21 & 1.525 & 0.0575 & 1789.618 & 4.4325 \\
\hline 4 & $\mathbf{T}_{3}$ & 77.75 & 30.3975 & 7.6625 & 15.9225 & 23.585 & 1.575 & 0.0175 & 1833.41 & 1.355 \\
\hline 5 & $\mathbf{T}_{4}$ & 93.25 & 34.215 & 8.6 & 15.705 & 24.305 & 1.575 & 0.015 & 2269.275 & 1.395 \\
\hline 6 & $\mathbf{T}_{5}$ & 89.75 & 34.09 & 7.045 & 15.55 & 22.595 & 1.403 & 0.0575 & 2031.115 & 5.165 \\
\hline 7 & $\mathbf{T}_{6}$ & 95.25 & 37.28 & 7.99 & 13.495 & 21.485 & 1.5375 & 0.0625 & 2042.945 & 5.9475 \\
\hline 8 & $\mathbf{T}_{7}$ & 95.5 & 38.6275 & 8.2625 & 15.83 & 24.0925 & 1.656 & 0.0775 & 2300.638 & 7.395 \\
\hline 9 & $\mathbf{T}_{8}$ & 85.25 & 38.9325 & 6.73 & 15.9175 & 22.6475 & 1.3275 & 0.04 & 1930.198 & 3.4075 \\
\hline 10 & $\mathbf{T}_{9}$ & 90.5 & 37.5025 & 8.2825 & 15.095 & 23.3775 & 1.4125 & 0.0375 & 2114.94 & 3.395 \\
\hline 11 & $\mathbf{T}_{10}$ & 95.25 & 37.5825 & 8.2675 & 14.8325 & 23.1 & 1.675 & 0.0625 & 2201.205 & 5.9475 \\
\hline 12 & $\mathbf{T}_{11}$ & 97.25 & 41.485 & 9.245 & 17.24 & 26.485 & 1.907 & 0.095 & 2576.435 & 9.238 \\
\hline 13 & $\mathbf{T}_{12}$ & 93.75 & 39.215 & 7.7875 & 16.1525 & 23.94 & 1.4125 & 0.0775 & 2244.903 & 7.275 \\
\hline 14 & Grand Mean & 89.5 & 36.00904 & 7.885769 & 15.32846 & 23.21423 & 1.554308 & 0.054038 & 2086.506 & 4.959077 \\
\hline 15 & C.D (5\%) & 4.057 & 3.878 & 1.081 & 1.343 & 1.917 & 0.149 & 0.032 & 210.244 & 3.104 \\
\hline 16 & SE(m) & 1.413 & 1.351 & 0.376 & 0.468 & 0.668 & 0.052 & 0.011 & 73.222 & 1.081 \\
\hline 17 & $\operatorname{SE}(d)$ & 1.998 & 1.910 & 0.532 & 0.661 & 0.944 & 0.073 & 0.016 & 103.552 & 1.529 \\
\hline
\end{tabular}



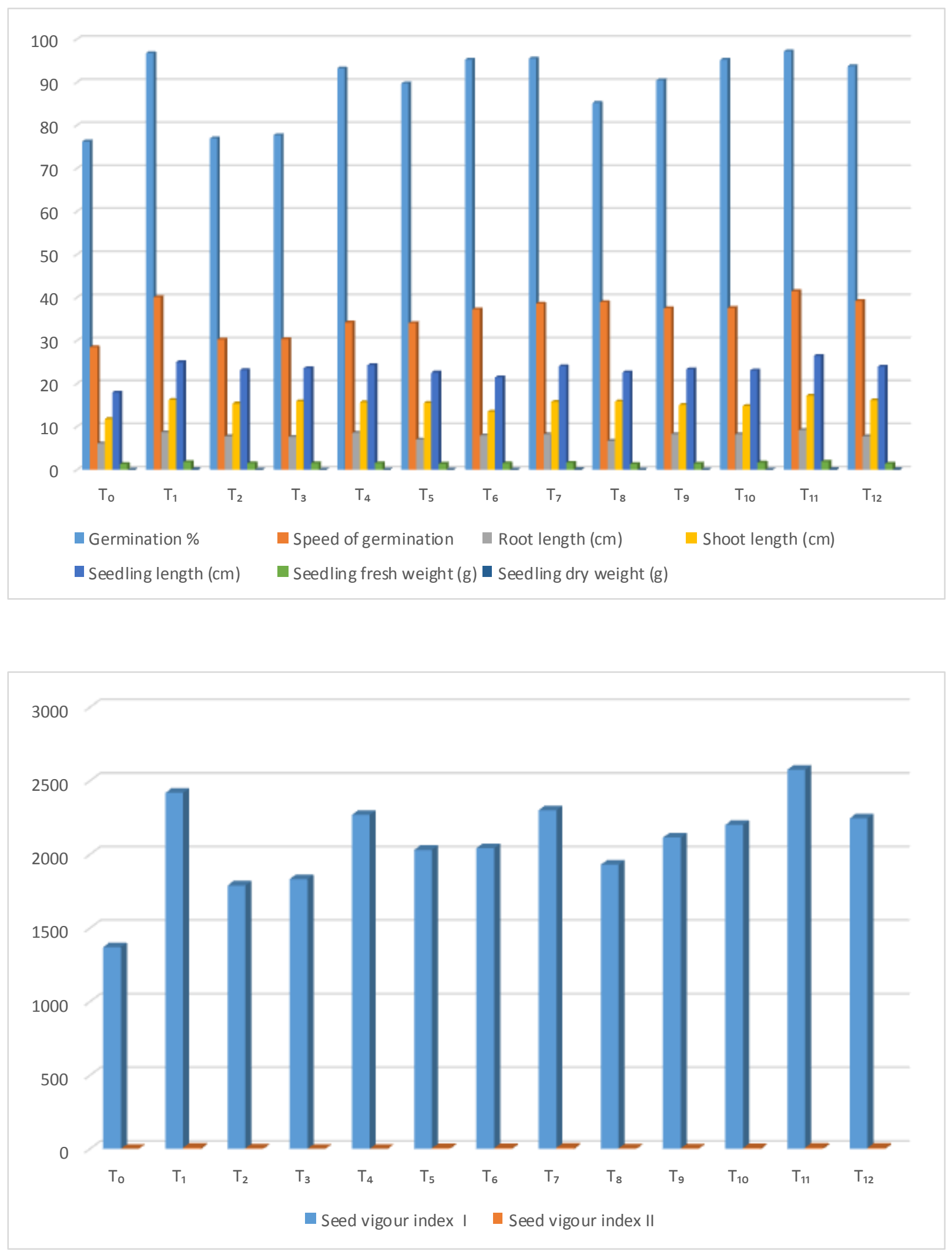


\section{Seedling dry weight (g)}

Seedling Dry Weight (g) was determined by different seed treatments. Mean performance of seedling dry weight ranged from $0.095 \mathrm{~g}$ to 0.015 with mean value of 0.054038 . Seeds treated with Moringa Leaf Extract (5\%) $\left(\mathrm{T}_{11}\right)$ accomplished significantly highest dry Weight of seedling (0.095g) followed by distilled water i.e., hydro priming $\left(\mathrm{T}_{1}\right)$ with (0.085). The minimum (0.015) was observed in $\mathrm{KNO}_{3} \quad(1 \%)\left(\mathrm{T}_{4}\right)$. Similar results of seedling dry weight were discussed by Afzal et al., (2012), Azra Yasmeen et al., (2013) and Hala et al., (2017).

\section{Seedling vigour index I}

Seedling Vigour Index I was significantly influenced by different seed treatments. Mean performance of vigour index ranged from 2576.435 to 1371.18 with mean value of 2086.506. Seeds treated with Moringa Leaf Extract $(5 \%) \quad\left(\mathrm{T}_{11}\right)$ recorded significantly highest vigour index I (2576.435) followed by distilled water i.e., hydro priming $\left(\mathrm{T}_{1}\right)$ with (2418.72). The minimum (1371.18) was observed in control $\left(\mathrm{T}_{0}\right)$. Similar results of seed vigour index I were discussed as Afzal et al., (2012, Wasif Nouman et al., (2012), Azra Yasmeen et al., (2013), Hala et al., (2017) and H.A. Wajid et al., (2018).

\section{Seedling vigour index II}

Seedling vigour Index II was determined by different seed treatments. Mean performance of vigour index ranged from 9.238 to 1.3025 with mean value of 4.95907. Seeds treated with Moringa Leaf Extract (5\%) $\left(\mathrm{T}_{11}\right)$ accomplished significantly highest vigour index II (9.238) followed by distilled water i.e, hydro priming $\left(\mathrm{T}_{1}\right)$ with $(8.2125)$. The minimum (1.3025) was observed in control $\left(\mathrm{T}_{0}\right)$. Similar results of seed vigour index 2 were discussed by Afzal et al., (2012), Wasif Nouman et al., (2012), Azra Yasmeen et al., (2013) and H.A. Wajid et al., (2018).

From the present investigation it was concluded that all the seed priming methods performed better but treatment with Moringa Leaf Extract (MLE) (5\%) (organic priming) was found to be best over all the other treatments in respect of germination and quality parameters. The extract of Moringa (5\%) i.e. organic priming method was very effective alternatives to popular priming strategies and are not only organic but are also cheap, easily adapted, and environmentally friendly. However, there is a need to explore more deeply of these sources to find out their importance in comparison with synthetic priming sources.

\section{References}

Bekim Gashi1, Kasamedin Abdullai1, Valbona Mata and Efigjeni Kongjika (2012). Effect of gibberellic acid and potassium nitrate on seed germination of the resurrection plants Ramonda serbica and Ramonda nathaliae, African Journal of Biotechnology Vol. 11(20), pp. 4537-4542.

Ercument Osman Sarihan, Arif Ipek, Khalid Mahmood Khawar, Mehmet Atak And Bilal Gurbuz (2005). Role of GA3 and KNO3iIn improving the frequency of seed germination in Plantago Lanceolata L, Pak. J. Bot., 37(4): 883887.

Ghassemi-Golezani K., A.A.Aliloo, M. Valizadeh, M. Moghaddam (2008). Effects of different priming techniques on seed invigoration and seedling establishment of lentil, Journal of Food, Agriculture and Environment Vol.6 (2): 222-226.

GUO Su-juan, WANG Wen-shu (Yong-chao, WANG 2012). Effects of priming 
treatments on germination and biochemical characteristics of Pinus bungeana seeds, For. Stud. China, 14(3): 200-204.

Hossein Reza Rouhi1, Ali Moradi, Maryam Saman and Roya Mahmoudieh Champiri (2018). Seed hydropriming to overcome ageing damages in Coriander (Coriandrum sativum L.) seeds, Academia Journal of Agricultural Research 6(10): 354-358.

Panumart Rithichai, Pattranuch Sampantharat and Yaowapha Jirakiattikul (2009). Coriander (Coriandrum sativum 1.) seed quality as affected by accelerated aging and subsequent hydropriming, As. $J$. Food Ag-Ind, Special Issue, S217-S221. Sang In Shim, Jun-Cheol Moon, Cheol Seong
Jang, Paul Raymer, Wook Kim1 (2008). Effect of Potassium Nitrate Priming on Seed Germination of Seashore Paspalum, HORTSCIENCE 43(7): 2259-2262.

Sevil Saglam, Sibel Day, Gamze Kaya, Aysegul Gurbuz (2010). Hydropriming Increases Germination of Lentil under Water Stress, Notulae Scientia Biologicae 2 (2): 103-106.

Wondimu Teshome1, Tamado Tana, Nigussie Dechassa, T. N. Singh (2018). Effect of Seed Priming on Germination and Seedling Growth of Grain Sorghum (Sorghum bicolor L. Moench) Varieties, East African Journal of Sciences Volume 12 (1) 51-60.

\section{How to cite this article:}

Neha Reddy, A., A. K. Chaurasia and Ehunme Sutnga. 2020. Assessment of Different Priming Methods on Germination and Quality Parameters of Coriander (Coriandrum sativum L.). Int.J.Curr.Microbiol.App.Sci. 9(11): 3030-3038. doi: https://doi.org/10.20546/ijcmas.2020.911.367 